\title{
EXTENDED ATMOSPHERES AND
}

CIRCUMSTELLAR MATTER

\section{IN SPECTROSCOPIC BINARY SYSTEMS}

Edited by A. H. BATTEN
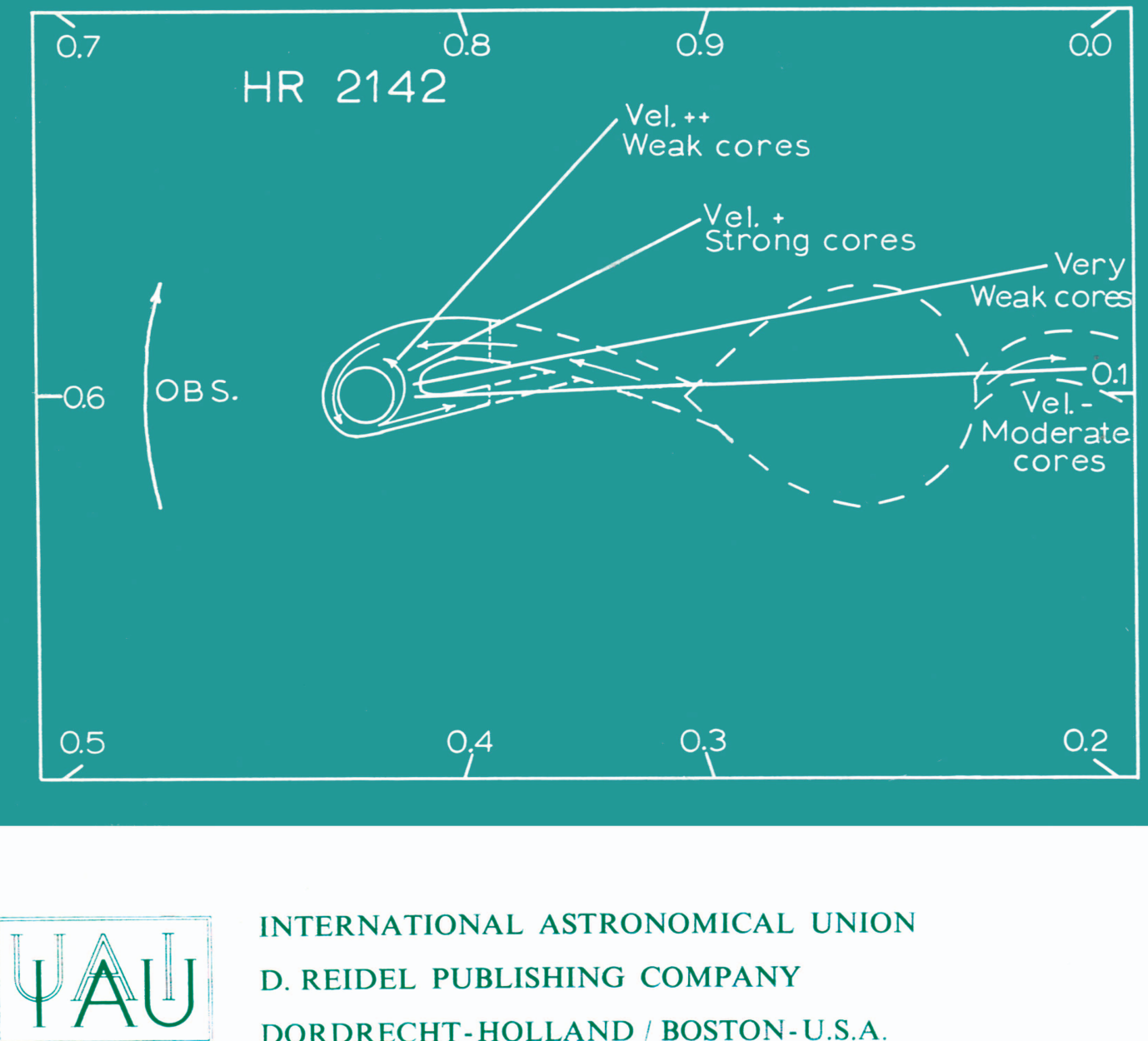

INTERNATIONAL ASTRONOMICAL UNION

D. REIDEL PUBLISHING COMPANY

DORDRECHT - HOLLAND / BOSTON-U.S.A. 
EXTENDED ATMOSPHERES

AND CIRCUMSTELLAR MATTER

IN SPECTROSCOPIC

BINARY SYSTEMS

SYMPOSIUM No. 51

The meeting was attended by fifty-six astronomers. The main topics covered were: observations of the flow of matter within binary systems; problems of gaseous motion around stars; expanding envelopes of stars; observations of stellar spectra related to extended atmospheres; theory of extended and expanding atmospheres; and evolutionary aspects of circumstellar matter in binary systems.

Readership:

Graduate students and professional astronomers. 


\section{EXTENDED ATMOSPHERES AND CIRCUMSTELLAR MATTER}

IN SPECTROSCOPIC BINARY SYSTEMS 


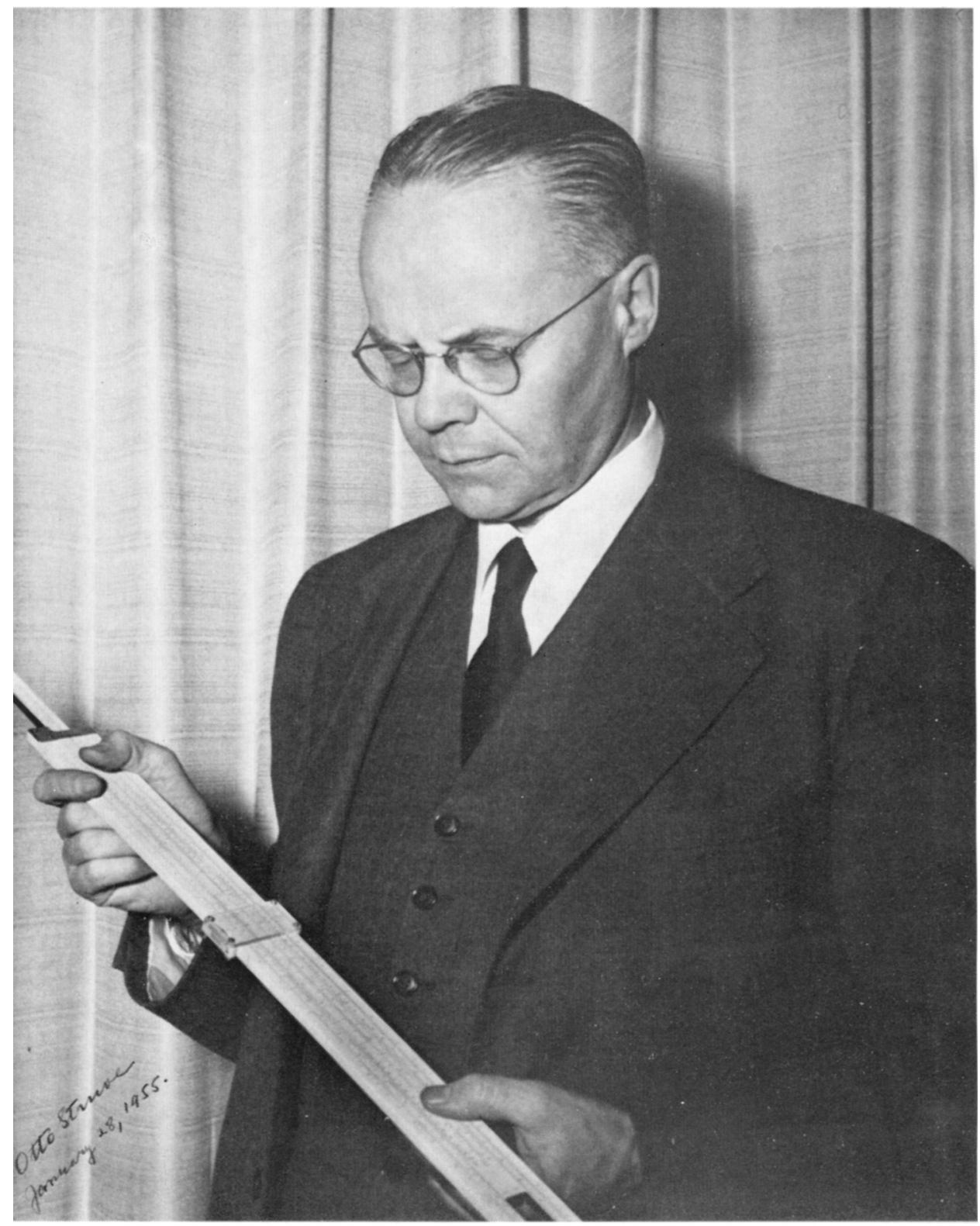

PROF. OTTO STRUVE

(1897-1963) 
INTERNATIONAL ASTRONOMICAL UNION

UNION ASTRONOMIQUE INTERNATIONALE

SYMPOSIUM No. 51

(STRUVE MEMORIAL SYMPOSIUM)

HELD AT PARKSVILle, B.C., CANADA, 6-12 SEPTEMBER, 1972

\title{
EXTENDED ATMOSPHERES AND CIRCUMSTELLAR MATTER IN SPECTROSCOPIC BINARY SYSTEMS
}

\author{
EDITED BY \\ A. H. BATTEN \\ Dominion Astrophysical Observatory, Victoria, B.C.
}

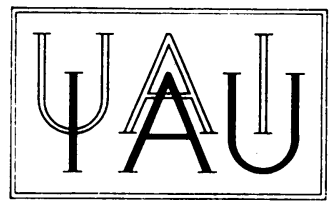

D. REIDEL PUBLISHING COMPANY DORDRECHT -HOLLAND / BOSTON-U.S.A.

1973 


\author{
Published on behalf of \\ the International Astronomical Union \\ by \\ D. Reidel Publishing Company, P.O. Box 17, Dordrecht, Holland \\ All Rights Reserved \\ Copyright (c) 1973 by the International Astronomical Union
}

Sold and distributed in the U.S.A., Canada, and Mexico

by D. Reidel Publishing Company, Inc.

306 Dartmouth Street, Boston,

Mass. 02116, U.S.A.

Library of Congress Catalog Card Number 72-97942

ISBN 9027703515

No part of this book may be reproduced in any form, by print, photoprint, microfilm, or any other means, without written permission from the publisher

Printed in The Netherlands by D. Reidel, Dordrecht 
This volume and the symposium of

which it is a record are dedicated to the memory of

\section{OTTO STRUVE (1897-1963)}

a former president of the International Astronomical Union

$$
\text { (1952-1955) }
$$

whose pioneer research created the field of study

to which the symposium was devoted 


\section{TABLE OF CONTENTS}

INTRODUCTION VII

LIST OF PARTICIPANTS XIII

ALAN H. BATtEN / Discussion of Observations of the Flow of Matter Within Binary Systems

SU-Shu huAng / Problems of Gaseous Motion Around Stars 22

First Discussion Session $\quad 48$

Second Discussion Session $\quad 61$

A. A. BOYARCHUK / Expanding Envelopes of Stars 81

Third Discussion Session $\quad 95$

K. O. WRIGHT / Observations of Stellar Spectra Related to

$\begin{array}{ll}\text { Extended Atmospheres } & 117\end{array}$

Fourth Discussion Session 134

KARL-HEINZ BÖHM / The Theory of Extended and Expanding $\begin{array}{ll}\text { Atmospheres } & 148\end{array}$

Fifth Discussion Session $\quad 171$

$\begin{array}{ll}\text { Sixth Discussion Session } & 174\end{array}$

Seventh Discussion Session 192

MIROSLAV PLA VEC / Evolutionary Aspects of Circumstellar Matter in Binary Systems 216

Eighth Discussion Session $\quad 260$

Ninth Discussion Session $\quad$ • 263

$\begin{array}{ll}\text { Tenth Discussion Session } & 277\end{array}$

JORGE SAHADE / Summary 286 